\title{
The effect of zinc therapy on electrolyte balance in children with acute diarrhea
}

\author{
Nicoleta Negrut, ${ }^{1,2}$ \\ From The 9th Edition of the Scientific Days of the National Institute for Infectious Diseases Prof Dr Matei Bals \\ Bucharest, Romania. 23-25 October 2013
}

\section{Background}

Electrolyte disturbances in acute diarrhea may occur with insufficient intake or excessive loss of ions. Treatment with zinc salt was recommended by WHO and UNICEF since 2008 for children under 5 years old.

\section{Methods}

During 2009-2011, children with acute diarrhea were enrolled in a randomized, open comparative study. Zinc salt was given to the patients from the study group according to WHO recommendations. The outcomes were the serum sodium, potassium and chloride levels in days 1, 2 and 3 of zinc therapy. Data were processed using EPIINFO version 6.0.

\section{Results}

In the above-mentioned time span 116 children, 0-3 years old, were enrolled. A total of 103 children recruited were available for analysis. In the study group $(n=53)$ compared with the control group $(n=50)$, there was no significant difference in serum sodium, potassium and chloride level ( $p>0.05$ ), on days 1,2 , and 3. Similarly, there was no significant difference between the concentrations of electrolytes in the two groups followed daily.

\section{Conclusion}

Zinc therapy in acute diarrhea does not seem to influence serum electrolytes in children under 3 years old.

\section{Authors' details}

${ }^{1}$ Third Department of Pediatrics, luliu Hațieganu University of Medicine and Pharmacy, Cluj-Napoca, Romania. ${ }^{2}$ Department of Neuroscience and

Recovery, Faculty of Medicine and Pharmacy, University of Oradea, Romania.

\footnotetext{
Correspondence: negrut.mihaela@umfcluj.ro

'Third Department of Pediatrics, luliu Hațieganu University of Medicine and Pharmacy, Cluj-Napoca, Romania

Full list of author information is available at the end of the article
}

Published: 16 December 2013

doi:10.1186/1471-2334-13-S1-P61

Cite this article as: Negruț: The effect of zinc therapy on electrolyte balance in children with acute diarrhea. BMC Infectious Diseases 2013 13(Suppl 1):P61.
Submit your next manuscript to BioMed Central and take full advantage of:

- Convenient online submission

- Thorough peer review

- No space constraints or color figure charges

- Immediate publication on acceptance

- Inclusion in PubMed, CAS, Scopus and Google Scholar

- Research which is freely available for redistribution

Submit your manuscript at www.biomedcentral.com/submit
C Biomed Central

\section{Biomed Central}

